\title{
Economic and other determinants of political trust
}

\author{
William DiPietro, PhD. \\ Professor, Daemen College, 4380 Main St., Amherst, NY 14226, United States
}

\begin{abstract}
Political trust is important for the effective functioning of government. This paper uses cross country regression analysis to see whether three different measures of economic performance matter for political trust. The results lend support to the hypothesis that political trust is influenced by economic growth, the standard of living, and the appropriate use of government spending. In addition, the paper considers two institutional variables, perceived independence of the judiciary and the degree of democracy to assess their effect on political trust. It finds that perceived judicial independence has a positive effect on political trust, but democracy has a negative effect.
\end{abstract}

Keywords: Political Ttrust; Growth; Government Waste; Per Capita GDP; Democracy and Judical Independence

\section{(C) 2013 Published by SSBFNET}

\section{Introduction}

Political trust, trust in politicians and the political system, is the foundation for a stable political system, and a stable political system is a key precondition that provides the essential environment for a healthy economy. An adequate (sufficient) level of political trust is needed to maintain the legitimacy of a political system and to perpetuate its continual existence. Insufficient levels of political trust can lead to discontent. This, in turn, can create tensions between citizens, with desires to change or possibly even overthrow the government, and the government, which is apt to resist undesired activities by repression or other means. While many people have found that perceived overall economic performance matters for political trust, this paper, hopefully, gives greater insight into the role of economic performance on political trust by considering three different dimensions of actual economic performance on political trust, the standard of living, economic growth, and government spending waste. The study is also unique in that it investigates a large cross section of countries without using World Value Survey data.

The paper is divided into five sections. The first section reviews a few of the relevant articles in the literature. The second section presents a simple political trust model, and discusses the variables that will be considered in the empirical section. The third section documents the sources of the variables. The fourth section presents the empirical results, and the fifth and final section concludes.

\footnotetext{
${ }^{*}$ Corresponding author. Tel.: 1-716-839-8427; fax: 1-716-839-.8261

E-mail address: wdipietr@daemen.edu
} 


\section{Brief Overview of Some of the Literature}

Applying a vector autoregressive model on quarterly data for the U.S. from 1980 to 1997, Chanley, Rudolph, and Rahn find that favorable economic expectations have a positive effect on public trust in government, but that greater sensitivity to crime, higher concern for international affairs, and congressional scandals have a negate effect (Chanley, Rudolph, and Rahn 2000). Keele estimates a single equation error correction model on quarterly data from 1970 to 2000 (Keele 2007). He finds that, in addition to economic performance and government institutional performance as measured by congressional approval, social capital, especially in the long run, seems to exercise a strong influence on people's trust in government. Ligthart and Oudheusden focus on fiscal decentralization. Looking at household survey data on 35,259 individuals for thirteen countries over the period 1994 through 2007, and estimating using an ordered logit model, they find that fiscal decentralization leads to greater trust in government (Ligthart and Oudheusden 2011). They also find that government size and income inequality have a negative effect on government trust, but, surprisingly, that government quality and macroeconomic performance do not seem to matter.

Two potential sources of diffuse political support are the socialization process and identity-based trust (the common trust that is based on common group identity). In countries that have just undergone a political transition, although diffuse political support from the socialization process may impact political trust negatively because the populace has been subject to the socialization of the previous government, diffuse political support arising from identity- based trust, depending on the situation, could still be positive. Askvik employs regression analysis on survey data for South Africa from 1995, 2001, and 2006, the years following its transition from an apartheid government to a democratic government (Askvik 2010). His results show that performance and diffuse support founded on identity-based trust are positive determinants of political trust for South Africa.

Using the 2006 Asia Barometer survey containing a sample of 1006 adults from face to face interviews, Wong, Hsiao, and Wan, compare political trust between Taiwan, with similar socio-economic conditions, but a more democratic government, and Hong Kong (Wong, Hsiao, and Wan 2009). They look at a whole host of potential political trust determinants in the five broad areas of government performance, culture, satisfaction with democratic rights and freedoms, life satisfaction, and personal individual characteristics. Among other results, their ordinary least squares regressions for the two different countries show that trust in the judiciary and economic performance are important for political trust in both countries, but more so for Taiwan than for Hong Kong, and that, while respect for tradition plays a role in Taiwan, it is unimportant in Hong Kong. Kim uses the Asia Barometer survey to compare the countries of Japan and South Korea for the years 2003, 2004, and 2006 (Kim 2010). Her regression analysis indicates that for Japan, in separate regressions for each of the three years, trust in the central government is consistently positively related to perceived performance with regard to the economy, the quality of public services, and the control of corruption, and, a dimension of self-expression, the right to criticize government, is also important for trust in the central government in two of the three years, 2004 and 2006. In Korea, perceived performance with regard to the economy is relevant for trust in central government in all three years, and the control of corruption in two of the three years, but, unlike Japan, the right to criticize government does not appear to be relevant in any of the three years.

\section{The Model}

The model is a single equation model that theorizes that political trust depends on economic variables and on institutional variables. The simple equation is as follows:

$$
\mathrm{T}=\mathrm{f}(\mathrm{E}, \mathrm{I})
$$


In the equation $\mathrm{T}$ is political trust, $\mathrm{E}$ is a vector of economic variables, and $\mathrm{I}$ a vector of institutional variables.

It seems an almost unquestioned accepted truism of public forum and discussion that politicians are judged and trusted on the basis of economic performance. The often heard saying "it's the economy stupid" from one of the past presidential elections in the United States captures the essence this idea and really drives home the point. The three macroeconomic variables selected for investigation and exploration are the overall state of the economy (the standard of living), the extent of economic growth, and the degree of waste in government spending. A better economy and higher levels of economic growth are expected to increase public trust in politicians, while ineffective government spending is predicted to reduce public government trust. The two institutional variables that are considered are the independence of the judiciary and the amount of democracy. It is anticipated that a stronger and more independent judiciary is positively associated with political trust as it causes the populace to have more faith in the fairness and the justice of the entire political system. Similarly, it is anticipated that there will be a positive relationship between democracy and political trust, as, traditionally, the lack of democracy has been associated with tyranny and repression. In fact, due to strong believe in the superiority of democracy to other forms of government, some of the past administrations in the U.S. have been devoted to the spread of democracy throughout the world.

\subsection{Sources for the Variables}

The measures of political trust (public trust in politicians), judicial independence, and government consumption waste come from the Global Competitiveness Report of the World Economic Forum (World Economic Forum 2009).

The political trust (public trust in politicians) ranges from one to seven. Higher values indicate greater political trust. Political trust is based on answers to the question, "how would you rate the level of public trust in the ethical standards of politicians in your country?" Similarly, the measure of judicial independence has potential values from one to seven, and is based on the answers to the question, "to what extent is the judiciary in your country independent from influence of members of government, citizens, or firm?" Lastly, waste in government spending is founded on the answers to the question, "how would you rate the composition of public spending in your country?" The government spending waste question has potential responses ranging from a low value of one (extremely wasteful) to a high value of seven (highly efficient in providing necessary goods and services). Because the index is inverted (with higher values indicating less government consumption waste), the paper, to make it more intuitively appealing, uses eight minus the World Economic Forum's wastefulness of government spending index. Each of the three indices represents the weighted average of the answers to their questions from 2009 through 2010. The measure of overall economic conditions (the standard of living) is real GDP per capita in constant 2000 U.S. dollars for the year 2005. The measure of economic growth is the average percentage annual growth rate for the three years 2007, 2008, and 2009. The data source both of these variables is the World Bank (World Bank 2009). Finally, the measure of the extent of democracy is the Economist's Intelligence unit democracy index for 2008 (The Economist 2008). This index moves between zero and ten. Higher values indicate greater democracy.

\section{Empirical Findings}

Table I shows the results of cross country regressions of the extent of trust in politicians on economic variables, and on economic variables adjusting for institutional variables. The first equation shows the level of trust in politicians on the standard of living (GDPPC). The second equation is the regression of 
the degree of trust in politicians on the standard of living (GDPPC) and on economic growth (GROWTH). The third equation seeks to assess the importance of the effective use of public funds on political trust. It adds the perceived waste of government spending (WASTE) to the variables used in the second equation. The fourth and fifth equation tack institutional variables onto the three economic variables of the third equation. The institutional variables appended are the perceived independence of the judiciary (JUDICIARY) and the extent of democracy (DEMOCRACY).

The table is set up with the first row numbering the regression equations, the first column listing the explanatory variables, and the last two rows showing respectively the r-squared values (RSQ) and the number of countries entering the equations $(\mathrm{N})$. The estimated coefficients appear as the top numbers in the cells in the center of the table. Underneath the estimated coefficients, in parenthesis, are their individual t-statistics. Variables significant at the one percent level of significance or better in an equation are marked with a single asterisk under the individual t-statistic, those significant at the five percent level or better are marked with two asterisks and those significant at the ten percent level or better are marked with three asterisks.

Table 1: Results of cross country regressions of the extent of trust in politicians

\begin{tabular}{|c|c|c|c|c|c|}
\hline & (1) & (2) & (3) & (4) & (5) \\
\hline C & $\begin{array}{c}2.548 \\
(24.90) \\
*\end{array}$ & $\begin{array}{c}2.120 \\
(15.47) \\
*\end{array}$ & $\begin{array}{c}7.180 \\
(23.16) \\
*\end{array}$ & $\begin{array}{c}5.772 \\
(11.49) \\
*\end{array}$ & $\begin{array}{c}5.476 \\
(10.90) \\
*\end{array}$ \\
\hline$G D P P C$ & $\begin{array}{c}.000063 \\
(8.45) \\
*\end{array}$ & $\begin{array}{c}.000073 \\
(9.77) \\
*\end{array}$ & $\begin{array}{c}.000030 \\
(6.03) \\
*\end{array}$ & $\begin{array}{c}.000017 \\
(2.89) \\
*\end{array}$ & $\begin{array}{c}.000021 \\
(3.56) \\
*\end{array}$ \\
\hline GROWTH & & $\begin{array}{c}.100 \\
(4.17) \\
*\end{array}$ & $\begin{array}{c}.031 \\
(2.19) \\
* *\end{array}$ & $\begin{array}{c}.035 \\
(2.53) \\
* *\end{array}$ & $\begin{array}{c}.023 \\
(1.68) \\
* * *\end{array}$ \\
\hline WASTE & & & $\begin{array}{c}-.959 \\
(-16.98) \\
*\end{array}$ & $\begin{array}{c}-.816 \\
(-11.97) \\
*\end{array}$ & $\begin{array}{c}-.717 \\
(-9.74) \\
*\end{array}$ \\
\hline$J U D I C I A R Y$ & & & & $\begin{array}{c}.210 \\
(3.48) \\
*\end{array}$ & $\begin{array}{c}.304 \\
(4.60) \\
* \\
\end{array}$ \\
\hline DEMOCRACY & & & & & $\begin{array}{c}-.085 \\
(-2.95) \\
*\end{array}$ \\
\hline$R S Q$ & .347 & .427 & .827 & .842 & .853 \\
\hline$N$ & 136 & 132 & 131 & 131 & 130 \\
\hline
\end{tabular}

The results lend strong support to the hypothesis that economic factors are important determinants of political trust. Each of the three economic variables, the standard of living, economic growth, and wastefulness in government spending are significant at the ten percent level of significance or better in each and every one of the equations in which they appear. The standard of living is significant at the one percent level of significance in all five equations, the extent of government spending waste is significant at the one percent level of significance or better in the three equations that it enters, while economic growth is significant at the one percent level or better in one of the four equations, significant at the five 
percent level or better in two of the four equations, and significant at the ten percent level of significance or better in one of the four equations in which it appears. In addition, each of the three economic variables estimated coefficients have their theoretically predicted signs. Just as expected, improvement in either economic conditions or the rate of economic growth increases public trust in politicians, whereas, higher perceived government spending waste reduces public trust in politicians.

Looking at equation (3) shows that the three economic variables, when used combination, explain over eighty two percent of the cross country variation of trust in politicians for a sample of one hundred and thirty one countries.

The economic variables are not just relevant when used together in isolation, but continue to be important after adjusting for institutional factors. Looking at equations four and five, which adds the institutional variables independence of the judiciary and the extent of democracy to the three economic variables of equation three, show that the standard of living and waste in government spending variables continue to be significant at the one percent level of significance or better, and that economic growth manages to stay significant at the ten percent level of significance or better. Thus, according to the empirical results found here, if governments want to foster public trust, it would be beneficial for them to increase overall economic growth and improve the efficiency of their operations. The two institutional variables, the independence of the judiciary and the extent of democracy, are also statistically important. Both variables are significant at the one percent level of significance or better in the equations in which they appear. While the negative sign on the extent of democracy is somewhat of a surprise, the positive sign on the extent of independence of the judiciary is just as expected. It may perhaps be that the diffusion of power due to greater democracy leads to increased government gridlock resulting in greater public skepticism of government and lowered public trust in politicians.

\section{Conclusion}

The study provides evidence that three components of actual economic performance, the standard of living, economic growth, and the extent of government spending waste, matter for political trust. The cross country regressions show that the three actual economic performance components are important for political trust whether they are regressed in combination alone or after controlling for institutional variables. Together, without adjusting for institutional variables, in a one hundred thirty-one country sample, the three components explain over eighty two percent of the cross country variation in the political trust measure. The obvious implications are that in order to maintain political trust, so that a government can undergird its legitimacy and be in a position to be able to promote and to institute its desired policies, the government must be very careful to pay close attention to the actual economy. It must be sure that the standard of living is acceptable, that the growth rate is adequate, and that it spends wisely.

\section{References}

Askvik, Steinar. (2010). "The Dynamics of Political Trust in South Africa, 1995-2006," Politikon, 37(1), pp.25-44. Blind, Peri K. (2006). "Building Trust in Government in the Twenty-first century: Review of Literature and Emerging Issues", http:/unpan1.un.org/intradoc/groups/public/documents/un/unpan025062.pdf, 6/6/2011.

Chanley, Virginia A., Thomas J. Rudolph, and Wendy M. Rahn. (2000). "The Origins and Consequences of Public Trust in Government: A Time Series Analysis,” The Public Opinion Quarterly, 64(3), pp. 239-256.

Christensen, Tom and Per Laegreid.( 2002). "Trust in Government-the Relative Importance of Service Satisfaction, Political Factors and Demography", http://www.ub.uib.no/elpub/rokkan/N/N18-02.pdf, 6/6/2011. 
Kim, Soonhee. (2010). "Public trust in Government in Japan and South Korea: Does the Rise of Critical Citizens Matter?,"Public Administration Review, 70(5), pp.801-810.

Keele, Luke. (2007). "Social Capital and the Dynamics of trust in Government," American Journal of Political Science, 51(2), pp.241-254.

Ligthart, Jenny E. and Peter van Oudheusden.( 2011). "In Government We Trust: the Role of Fiscal Decentralization," Preliminary Draft, http://www.tilburguniversity.edu/research/institutes-and-researchgroups/center/staff/ligthart/defacto.pdf, 6/9/2011.

Morris, Stephen D. and Joseph L. Klesner. (2010). "Corruption and Trust: Theoretical Considerations and Evidence From Mexico", Comparative Political Studies, 43(10), pp.1258-1286, http://www.vanderbilt.edu/lapop/news/092410a.pdf, 6/6/2011.

The Economist. (2008). The Economist Intelligence Unit's democracy index. http:/graphics.eiu.com/PDF/Democracy\%20Index\%202008.pdf, February, 17, 2011.

Wong, Timothy Ka-Ying, Hsin-Huang Michael Hsiao, and Po-San Wan. (2009). "Comparing Political Trust in Hong Kong and Taiwan: Level, Determinants, and Implications," Japanese Journal of Political Science, 10(2), PP. 147174.

World Bank.(2009). World Development Indicators Online. http://ddpext.worldbank.org.ezp.lib.rochester.edu/ext/DDPQQ/member.do?method=getMembers\&userid=1\&queryId=6, 6/13/2009.

World Economic Forum, Global Competitiveness Report 2009-2010. 2009. http://www.ioeemp.org/fileadmin/user_upload/documents_pdf/globaljobscrisis/generaldocs/gendocs_wefreport.pdf, 5/20/2011. 